\title{
ЗАСТОСУВАННЯ МІЖНАРОДНОЇ КЛАСИФІКАЦІЇ ФУНКЦІОНУВАННЯ, ОБМЕЖЕНЬ ЖИТТЄДІЯЛЬНОСТІ ТА ЗДОРОВ'Я ПРИ ВИКЛАДАННІ КЛІНІЧНИХ ДИСЦИПЛІН У ФІЗИЧНИХ TЕРАПЕВТIВ
}

\author{
I. R. Mysula, T. G. Bakalyuk, H. O. Stelmakh, Kh. Ya. Maksiv \\ I. Horbachevsky Ternopil State Medical University

\section{APPLICATION OF INTERNATIONAL CLASSIFICATION OF FUNCTIONING, LIMITATIONS OF LIFE AND HEALTH IN TEACHING OF CLINICAL DISCIPLINES IN PHYSICAL THERAPISTS}

\begin{abstract}
Анотація. У статті проаналізовано використання Міжнародної класифікації функціонування, обмежень життєдіяльності та здоров’я (МКФ) для вдосконалення викладання клінічних дисциплін бакалаврам та магістрам із спеціальності «Фізична терапія. Ерготерапія». Враховуючи сучасну парадигму охорони здоров’я та фізичної терапії з їх фокусуванням на функціонуванні людини, її активності й участі, реабілітаційний діагноз має базуватися на МКФ. Фізичному терапевту необхідно у своїй клінічній практиці орієнтуватися не на клінічний діагноз, а на МКФ в якості основи для постановки реабілітаційного діагнозу.

На кафедрі медичної реабілітації при проведенні практичних занять 3 клінічних дисциплін для бакалаврів та магістрів зі спеціальності «Фізична терапія. Ерготерапія» на основі обстеження пацієнта в межах компетенції фізичного терапевта складається список проблем, сформульованих у категоріях МКФ (функція, активність, участь), проводиться кількісне оцінювання прояву порушення або обмеження та визначається роль фактора зовнішнього середовища, після встановлення реабілітаційного діагнозу складається програма реабілітації, ефективність якої контролюється також за допомогою МКФ.

Бакалаври та магістри зі спеціальності «Фізична терапія. Ерготерапія» повинні навчитись орієнтуватися в МКФ і використовувати її для встановлення реабілітаційного діагнозу та розробки реабілітаційних програм.
\end{abstract}

Ключові слова: МКФ; фізичний терапевт; реабілітаційний діагноз; практичні заняття; реабілітаційні програми.

Abstract. The article analyzes the use of International Classification of Functioning, Limitations of Life and Health (ICF) to improve the teaching of clinical disciplines for bachelors and masters in the specialty "Physical therapy. Ergotherapy". Given the modern paradigm of health and physical therapy with their focus on human functioning, its activity and participation, the rehabilitation diagnosis should be based on the ICF. The physical therapist needs to focus in his clinical practice not on the clinical diagnosis, but on the ICF as the basis for setting the rehabilitation diagnosis.

At the department of medical rehabilitation during conducting practical classes on clinical disciplines for bachelors and masters in the specialty "Physical therapy. Ergotherapy" on the basis of a patient's examination within the competence of the physical therapist there is a list of problems formulated in the categories of the ICF (function, activity, participation), a quantitative assessment of the manifestation of violation or restriction is carried out and the role of the environmental factor is determined, after the establishment of the rehabilitation diagnosis, a program of rehabilitation, efficiency which is also controlled by ICF.

Bachelors and masters in the specialty "Physical therapy. Ergotherapy" should learn to navigate the ICF and use it to establish a rehabilitation diagnosis and develop rehab programs.

Key words: ICF; physical therapist; rehabilitation diagnosis; practical classes; rehabilitation programs.

() І. Р. Мисула, Т. Г. Бакалюк, Г. О. Стельмах, Х. Я. Максів 
Вступ. Сучасна реабілітація як комплексна мультидисциплінарна стратегія впливу на організм свідчить про необхідність розгляду пацієнта в рамках складної біопсихосоціальної системи, яка взаємодіє 3 навколишнім середовищем. Така модель покладена в основу широко використовуваної сьогодні у світовій медицині Міжнародної класифікації функціонування, обмежень життєдіяльності та здоров'я (МКФ) [1]. Протягом останнього десятиріччя у всьому світі почалося активне використання вищевказаної класифікації для побудови реабілітаційного діагнозу. Міністерство охорони здоров’я України також розпочало впровадження Міжнародної класифікації функціонування, що забезпечить перехід від апаратної до фізичної терапії, від пасивної до активної реабілітації, а також дозволить оцінювати кожен етап процесу реабілітації пацієнта. МКФ приєднує Україну до розвинених країн і повністю змінює підхід до визначення стану людини. У зв'язку з цим змінюються підходи до викладання клінічних дисциплін для фізичних терапевтів, що і визначило мету нашої роботи.

Мета статті - проаналізувати використання Міжнародної класифікації функціонування, обмежень життєдіяльності та здоров'я для вдосконалення викладання клінічних дисциплін бакалаврам та магістрам із спеціальності «Фізична терапія. Ерготерапія».

Теоретична частина. Аналізуючи МКФ та дані наукової літератури, можна зробити висновок, що іiї на сьогодні використовують як базову для побудови реабілітаційного діагнозу в процесі фізичної реабілітації осіб із порушенням опорно-рухового апарату, нервової системи та 3 психологічними порушеннями [2]. Тобто, враховуючи сучасну парадигму охорони здоров’я та фізичної терапії з їх фокусуванням на функціонуванні людини, ії активності й участі, реабілітаційний діагноз має базуватися на МКФ [5].

Фізичний терапевт у своїй клінічній діяльності зустрічається з багатьма захворюваннями, проте світовий досвід свідчить, що неприпустимо виходити тільки з позицій клінічного діагнозу, оскільки він описує тільки патологію і не зачіпає функціональний стан пацієнта, що є малоінформативним. Більш того, різноманітні клінічні діагнози можуть однаково зовні проявлятися на функціональному стані пацієнта (ДЦП, інсульт, пухлини мозку), і навпаки, одні і ті ж клінічні діагнози можуть сильно відрізнятися за функціональним станом пацієнта [1, 3].
МКФ покликана допомогти уніфікувати встановлення реабілітаційного діагнозу, визначити мету та завдання фізичної терапії, оцінити ефективність реабілітації, тому застосування даної класифікації допоможе описати порушення та обмеження, які виникають у людини внаслідок будь-якого захворювання, травми чи патологічного стану. Отже, фізичному терапевту необхідно у своїй клінічній практиці орієнтуватися не на клінічний діагноз, а на МКФ в якості основи для постановки реабілітаційного діагнозу [4].

Новим у сучасній реабілітації є мультидисциплінарна команда - організаційно оформлена, функціонально відокремлена група фахівців, які об'єднані спільними цілями реабілітаційного процесу, проводять реабілітацію високої інтенсивності в закладах охорони здоров'я стаціонарного й амбулаторного типів у гострому, підгострому та довгостроковому реабілітаційних періодах. Формою роботи мультидисциплінарної команди є збори, на яких після обговорення результатів реабілітаційного обстеження визначається індивідуальна програма реабілітації, розглядаються показники моніторингу й оцінки виконання програми та здійснюється ії коригування [5].

Реабілітаційний діагноз, який встановлюється кожним членом мультидисциплінарної бригади, заснований на МКФ, і саме це може забезпечити спільну мову для опису функціонування людини i, отже, полегшує міждисциплінарну діяльність, відповідальність та координацію втручань [5].

Визначення цілей реабілітації та розподілення відповідальності між різними фахівцями реабілітаційної бригади дозволяють, з одного боку, незалежно виконувати свою роботу, з іншого - робити внесок у формування нового функціонального статусу пацієнта з точною координацією своїх дій 3 іншими фахівцями [4].

На кафедрі медичної реабілітації при проведенні практичних занять з клінічних дисциплін для бакалаврів та магістрів зі спеціальності «Фізична терапія. Ерготерапія» на основі обстеження пацієнта в межах компетенції фізичного терапевта складається список проблем, сформульованих у категоріях МКФ (функція, активність, участь), проводиться кількісне оцінювання прояву порушення або обмеження та визначається роль фактора зовнішнього середовища, після встановлення реабілітаційного діагнозу складається програма реабілітації, ефективність якої контролюється також за допомогою МКФ. 
Прийняття МКФ забезпечило основу для переосмислення реабілітації як стратегії в галузі охорони здоров’я та поставило реабілітацію на міцнішу концептуальну основу.

Висновки та перспективи подальших досліджень. 1. МКФ є навчальним інструментом і повинна використовуватися при розробці навчальних програм та застосовуватися на практичних заняттях.

2. Викладачу, який викладає клінічні дисципліни для студентів спеціальності «Фізична терапія. Ерготерапія», потрібно оволодіти МКФ і використовувати дану класифікацію на практичних заняттях.

\section{Список літератури}

1. Использование международной классификации функционирования (МКФ) в амбулаторной и стационарной медицинской реабилитации: инструкция для специалистов / Е. В. Мельникова, Т. В. Буйлова, Р. А. Бодрова [и др.] // Вестник восстановительной медицины. - 2017. № 6 (82). - С. 2-20.

2. Романишин Н. Я. Основы построения реабилитационного диагноза в клинической практике физическим реабилитологом / Н. Я. Романишин // Педагогіка, психологія та медико-біологічні проблеми фізичного виховання і спорту. - 2012. - № 1. - С. 94-96.

\section{References}

1. Melnikova, E.V., Buylova, T.V., \& Bodrova, R.A. (2017). Izpolzovaniye mezhdunarodnoy klasifikatsii funktsionirovaniya (MKF) v ambulatornoy i statsionarnoy meditsinskoy reabilitatsii: instruktsiya dlya spetsialistov [Use of the International Classification of Functioning (ICF) in outpatient and inpatient medical rehabilitation: A manual for specialists]. Vestnik vostanovitelnoy meditsiny - The Reporter of Restorative Medicine, 6 (82), 2-20 [in Russian].

2. Romanyshyn, N.Ya. (2012). Osnovy postroeniya reabilitatsyonnogo diagnoza $\mathrm{v}$ klinicheskoy praktike fizicheskym reabilitologom [Fundamentals of the construction of a rehabilitation diagnosis in clinical practice by a physical rehab]. Pedahohika, psykholohiia ta medykobiolohichni problemy fizychnoho vykhovannia i sportu -
3. Бакалаври та магістри зі спеціальності «Фізична терапія. Ерготерапія» повинні навчитись орієнтуватися в МКФ і використовувати ї̈ для встановлення реабілітаційного діагнозу та розробки реабілітаційних програм.

Перспективним є впровадження МКФ у клінічну практику, що сприятиме індивідуальному підходу до пацієнта при призначенні реабілітаційних втручань та контролюватиме реабілітаційний процес. Використовувати МКФ у практичній діяльності повинні всі члени мультидисциплінарної реабілітаційної команди.

3. International classification of functioning, disability and health: children \& youth version: ICF-CY / World Health Organization. - 2007. - P. 301.

4. Negrini S. Methodology of "Physical and rehabilitation medicine practice, evidence based position papers: the European position" produced by the UEMS-PRM section / S. Negrini, C. Kiekens, M. Zampolini // Eur. J. Phys. Rehabil. Med. - 2016. - Vol. 52, No. 1. - P. 134-141.

5 . White book on physical and rehabilitation medicine in Europe / European Journal of Physical and Rehabilitation Medicine. - 2018. - Vol. 54 (2). - P. 125-321.

Pedagogics, Psychology and Medical and Biological Problems of Physical Education and Sports, 1, 94-96 [in Russian].

3. (2007). International classification of functioning, disability and health: children \& youth version: ICF-CY. World Health Organization.

4. Negrini, S., Kiekens, C., \& Zampolini, M. (2016). Methodology of "Physical and rehabilitation medicine practice, evidence based position papers: the European position” produced by the UEMS-PRM section. Eur. J. Phys. Rehabil. Med., 52 (1), 134-141.

5. (2018). White book on physical and rehabilitation medicine in Europe. European Journal of Physical and Rehabilitation Medicine, 54 (2), 125-321. 